\title{
STRUKTUR KOMUNITAS IKAN DI SUNGAI LULAK DAN SUNGAI GENDIR KABUPATEN BANGKA BARAT
}

\author{
Fish Community Structure in Lulak Stream and Gendir Stream of West Bangka Regency \\ Aditia, Wahyu Adi dan Andi Gustomi \\ ${ }^{1}$ Jurusan Manajemen Sumberdaya Perairan, Fakultas Pertanian Perikanan dan Biologi, Universitas Bangka \\ Belitung, Balunijuk
}

Email korespondensi: aditiaa38@gmail.com

Diterima Februari 2020; disetujui April 2020; tersedia secara online April 2020

\begin{abstract}
The waters of the stream in West Bangka nowadays facing the threat of deforestation. As the impact, the forest was opened for other function such as for the plantations like agriculture mostly for the program of rice field print and it threaten the fish habitats, for instance, thefish habitats in Lulak stream and Gendir stream in Kelapa, West Bangka regency. The goals of this study are to examine the diversity of the fish, examine the community structure, and examine the relationship between the water quality with the fish diversity in Lulak Stream and Gendir Stream. The data was taken and conducted in February 2020 using the gill net and dip net. The result showed that the diversity value has the index with the amount is 1,948 for Lulak Stream and 1,881 for Gendir Stream with the category is moderate. The community structure of fish in Lulak stream and Gendir stream was dominated by Cyprinidae with 5 species from 14 species based on what was found in both of the streams. There was 14 fish with 12 fish species found in Lulak stream and 11 fish in Gendir stream that dominated by Cyprinidae (Puntius binotatus, Puntius lineatus, Cyclocheilichthys apogon dan Rasbora chepholataenia). The Physic and Chemistry factors in Lulak Stream and Gendir Stream supports the survival life of the cyprinidae that dominate both of the river.

Keywords: Fish Fiversity, Fresh Waters, Lulak Stream, Gendir Stream, Bangka
\end{abstract}

\section{PENDAHULUAN}

Deforestasi ataupun fragmentasi Alih fungsi lahan untuk perkebunan, pertanian terutama program cetak sawah di Bangka Barat telah mengancam habitat keberagaman jenis ikan di Sungai Lulak dan Sungai Gendir yang menyebabkan terjadinya degradasi habitat. Muchlisin dan Azizah (2009), menyatakan bahwa degradasi habitat menyebabkan turunnya kekayaan jenis dan keanekaragaman ikan, terutama pada ekosistem perairan yang tergenang. Kekayaan jenis ikan berperan penting dalam menggambarkan daya dukung lingkungan terhadap spesies ikan (Hargarave, 2009).

Sungai Lulak merupakan salah satu sungai yang terletak di Desa Kelapa Kecamatan Kelapa dan Sungai Gendir di Dusun Penegak Desa Simpang Yul Kecamatan Tempilang.Dua Sungai ini banyak dimanfaatkan oleh masyarakat bermata pencaharian pencari ikan. Umumnya di sekitar Sungai Lulak dimanfaatkan warga sebagai lahan pertanian, dan persawahan, sedangkan di Sungai Gendir dimanfaatkan warga sebagai lahan perkebunan kelapa sawit.Sungai Lulak di bagian hulu perairannya masih ditumbuhi hutan yang cukup lebat, sedangkan di bagian tengah dan hilir perairannya banyak aktivitas perkebunan dan persawahan. Sungai Gendir ini dari bagian hulu sampai hilir perairan semuanya perkebunan kelapa sawit. Akibat adanya aktivitas masyarakatdalam bidang tersebut, maka di sepanjang Perairan Sungai
Lulak dan Sungai Gendir diduga akan menyebabkan kondisi perairan terganggu dan mempengaruhi stabilitas ekosistem biota yang hidup di perairan tersebut. Apabila hal tersebut terjadi secara terus-menerus, dikhawatirkan kondisi ini akan mengancam struktur komunitas ikan yang ada di Sungai Lulak dan Sungai Gendir.

Menurut Effendi (2003), lahan pertanian yang dekat dengan badan sungai biasa menghasilkan polutan berupa pestisida yang masuk ke badan air melalui limpasan dari daerah pertanian. Hal ini menyebabkan sungai yang mengalir di dekat lahan pertainan tercemar oleh polutan sehingga habitat ikan di sungai tersebut menjadi terganggu sehingga pada akhirnya, keberagaman ikan di sungai tersebut menjadi berkurang. Oleh sebab itulah, perlu dilakukan penelitian untuk melihat keberagaman jenis ikan yang ada di Sungai Lulak dan Sungai Gendir.

\section{METODE PENELITIAN \\ Waktu dan Lokasi Penelitian}

Penelitian ini dilaksanakan pada bulan Februari 2020 di Sungai Lulak dan Sungai Gendir, Kabupaten Bangka Barat Provinsi Kepulauan Bangka Belitung.Sampel ikan diidentifikasi di Laboratorium Manajemen Sumberdaya Perairan(MSP) Fakultas Pertanian, Perikanan dan Biologi (FPPB), Universitas Bangka Belitung(UBB). Peta lokasi penelitian dapat dilihat pada Gambar 1. 

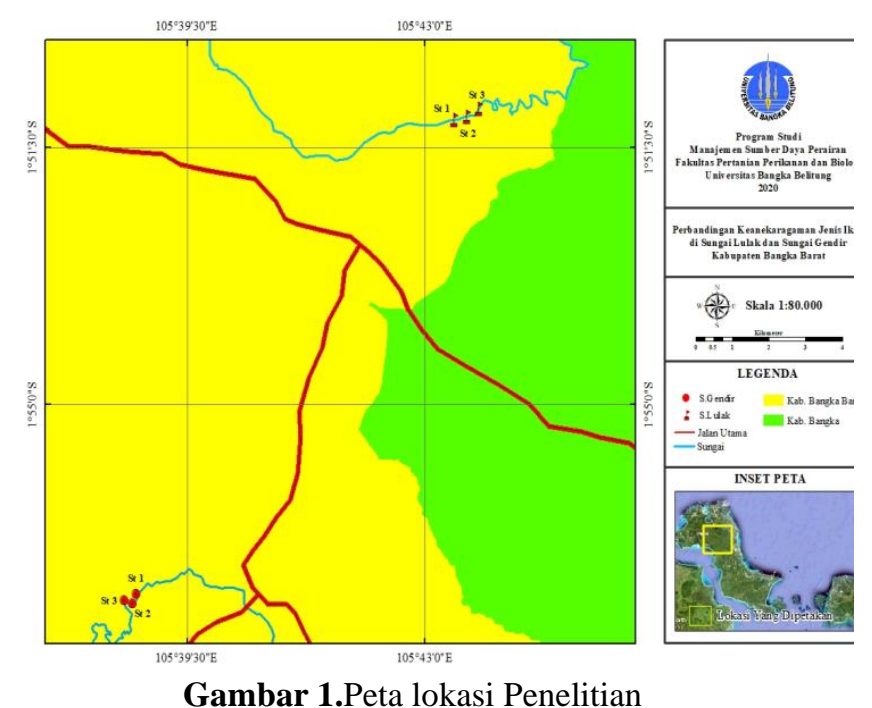

Gambar 1.Peta lokasi Penelitian

\section{Penentuan Stasiun Pengambilan Sampel}

Penentuan stasiun pengambilan sampel dilakukan dengan metode purposive sampling yaitu penentuan lokasi pengambilan sampel berdasarkan pertimbangan peneliti pada lokasi penelitian (Fachrul, 2006).Penelitian ini mengambil tiga stasiun dari setiap Sungai yang dianggap mewakili kondisi perairan Sungai Lulak dan Sungai Gendir, sehingga dapat memberikan gambaran mengenai keanekaragaman jenis ikan di sungai tersebut.Stasiun pengambilan data yaitu sebanyak 3 yaitu pada bagian hulu, pertengahan dan hilir sungai. Hulu, pertengahan dan hilir dianggap mewakili keseluruhan aliran sungai.

\section{Pengambilan Data Ikan}

Pengambilan sampel ikan diambil menggunakan dua alat tangkap yaitu jaring insang (Gill Net) dengan panjang jaring 15-25 meter, tinggi jaring 1-2 meter, meshsize 3\4inch, 1 inch, 1,5inch dan 2 inch, dan alat tangkap serok atau tangguk (Dip Net) dengan mesh size $1,5-2,0 \mathrm{~mm}$

Hasil yang telah didapatkan dicatat jumlah individunya, di dokumentasikan satu per satu untuk melihat komposisi jenis ikan pada setiap perairan baik perairan sungai Lulak maupun sungai Gendir, kemudian dimasukan kedalam larutan formalin 5-10\% agar sampel yang didapat dapat diawetkan dan kemudian diberi label pada tiap sampel. Selanjutya, Sampel ikan dicuci dan dibersihkan dari larutan formalin lalu disimpan dalam larutan alkohol $70 \%$ untuk diawetkan agar ikan yang didapat dapat diawetkan lebih lama. Sampel ikan yang telah diperoleh di lapangan kemudian dibawa ke Laboratorium Perikanan Fakultas Pertanian, Perikanan Dan Biologi Universitas Bangka Belitung untuk diidentifikasi menggunakan buku pedoman identifikasi dari Saanin, 1984.

\section{Pengkuran parameter fisika dan kimia perairan} Sampel perairan yang diambil terdiri dari parameter fisika (suhu, kecerahan, kedalaman, dan kecepatan arus), dan parameter kimia $(\mathrm{pH}$, oksigen terlarut (Dissolved Oxygen), nitrat dan fosfat.

\section{Analisis Data \\ Komposisi Jenis}

Analisis komposisi jenis dilihat dari Jumlah jenis ikan secara keseluruhan yang diperoleh dari stasiun yang ada (Setyobudiandi et al., 2009).

Kelimpahan Relatif

Perhitungan kelimpahan relatif setiap jenis ikan dilakukan dengan perhitungan persentase jumlah (Krebs, 1972 dalam Setyobudiandi et al., 2009):

$$
K r=\frac{n i}{N} \times 100 \%
$$

$\mathrm{Kr}:$ Kelimpahan relatif (\%)

Keterangan:

ni : Jumlah individu spesies ke-i

$\mathrm{N}$ : Jumlah total individu semua spesies

\section{Frekuensi Keterdapatan}

Frekuensi keterdapatan menunjukkan luasnya penyebaran lokasi jenis tertentu. Hal ini dapat dilihat dari frekuensi (\%) ikan yang tertangkap dengan persamaan (Setyobudiandi et al., 2009):

$$
F i=\frac{t i}{T} \times 100 \%
$$

Keterangan:

Fi : Frekuensi keterdapatan ikan spesies ke- i yang tertangkap (\%)

ti : Jumlah stasiun dimana spesies ke-i yang tertangkap

$\mathrm{T}$ : Jumlah semua stasiun

Penentuan kriteria :

Fi mendekati 100\% : Penyebaran ikan luas

Fi mendekati 0\% : Penyebaran ikan sempit

\section{Indeks Keanekaragaman}

Indeks keanekaragaman merupakan indeks yang sering digunakan untuk mengevaluasi keadaan suatu lingkungan perairan berdasarkan kondisi biologi. Untuk menentukan keanekaragaman ikan dihitung dengan indeks Shanon-Wiener (Setyobudiandi et al., 2009):

Keterangan:

$$
H^{\prime}=\sum_{t=1}^{s} \text { pi ln pi }
$$

$\mathrm{H}^{\prime}$ : Indeks Diversitas Shanon-Wiener

$\mathrm{Pi}: \mathrm{ni} / \mathrm{N}$

ni : Jumlah individu spesies ke-i

$\mathrm{N}$ : Jumlah individu semua spesies

Penentuan kriteria berdasarkan (Setyobudiandi et al., 2009):

$\mathrm{H}^{\prime}<1$ : Keanekaragaman rendah

$1<\mathrm{H}^{\prime}<3$ : Keanekaragaman sedang

$\mathrm{H}^{\prime}>3$ : Keanekaragaman tinggi

\section{Indeks Keseragaman}

Diversitas maksimum (Hmax) terjadi bila kelimpahan semua spesies di semua stasiun merata. Rasio keanekaragaman yang terukur dengankeanekaragaman maksimum dapat dijadikan ukuran keseragaman (E) yang dapat dihitung dengan persamaan (Setyobudiandi et al., 2009): 


$$
E=\frac{\mathbf{H}^{\prime}}{\mathbf{H} \text { maks }}
$$

Keterangan:

E : Indeks Keseragaman

H' : Indeks Keanekaragaman Shanon-Wiener

Hmaks : Keanekaragaman Maksimum

$\mathrm{S}$ : Jumlah Spesies

Penentuan kriteria berdasarkan (Setyobudiandi et al., 2009):

$\begin{array}{ll}\mathrm{E} \leq 0,5 & =\text { Keseragaman tinggi } \\ 0,5<\mathrm{E} \leq 0,75 & =\text { Keseragaman sedang } \\ 0,75<\mathrm{E} \leq 1 & =\text { Keseragaman tinggi }\end{array}$

Nilai indeks keseragaman berkisar antara 01.Indeks yang mendekati 0 menunjukan adanya jumlah individu yang terkonsentrasi pada satu atau beberapa jenis. Hal ini dapat diartikan ada beberapa jenis biota yang memiliki jumlah jenis individu relatif banyak.Sementara beberapa jenis lainnya memiliki jumlah individu yang relatif sedikit. Nilai indek keseragaman yang mendekati 1 menunjukan bahwa jumlah individu disetiap spesies adalah sama atau hampir sama.

\section{HASIL DAN PEMBAHASAN}

\section{Strktur Komunitas Ikan yang Terdapat di Sungai Lulak dan Sungai Gendir.}

Berdasarkan jumlah hasil tangkapan ikan yang didapat di Sungai Lulak dan Sungai Gendir, terdapat 14 spesies ikan yang ditemukan. Jenis-jenis ikan yang didapat dapat dilihat pada Tabel 1. famili ikan yang paling banyak dijumpai pada kedua perairan sungai adalah famili Cyprinidae. Terdapat 5 jenis ikan yang didapat dari famili Cyprinidae dari 14 jenis ikan yang didapat di kedua perairan (Sungai lulak dan gendir). Ikan yang ditemukan dari famili Cyprinidae adalah Ikan Kemuring (Puntius lineatus), Ikan Tanah (Puntius binotatus), Ikan Keperas (Cyclocheilichthys apogon), Ikan Kepait (Osetochilis spilurus), dan ikan Seluang (Rasbora chepholataenia). Ikan dari famili Cyprinidae yang mendominasi struktur komunitas ikan di perairan lulak adalah ikan dari spesies puntius sedangkan di perairan Sungai Gendir ikan keperas menjadi ikan yang png banyak didapatkan. Berdasarkan hasil penelitian, terdapat dua jenis spesies dari genus puntius yang didapatkann dari hasil penelitian. Genus Puntius termasuk kedalam famili Cyprinidae dengan ciri khas mempunyai dua pasang sungut. Puntius mempunyai karakteristik pada sisik yang mempunyai proyeksi dari

\section{Indeks Dominansi}

Untuk mengetahui ada tidaknya suatu dominansi, digunakan indeks dominansi Simpson (Setyobudiandi et al., 2009)

$$
C=\sum_{i=0}^{s}\left\lceil\frac{n i}{N}\right\rceil^{2}
$$

Keterangan:

C : Indeks Dominansi Simpson

ni : Jumlah individu spesies ke-i

$\mathrm{N}$ : Jumlah individu semua spesies ke-i

Penentuan kriteria berdasarkan (Setyobudiandi et al.,

2009):

$0<\mathrm{C}<0,5=$ Dominansi rendah.

$0,5<\mathrm{C} \leq 0,75=$ Dominansi sedang.

$0,75<\mathrm{C} \leq 1=$ Dominansi tinggi.

Nilai indeks dominansi berkisar antara $0-1$, indeks 1 menunjukan dominansi oleh satu jenis spesies sangat tinggi (hanya terdapat satu jenis pada satu stasiun), sedangkan indeks 0 menunjukan bahwa diantara jenisjenis yang ditemukan tidak ada mendominansi.

pusat ke pinggir terlihat seperti jari-jari pada roda, jarijari yang ke arah samping tidak melengkung ke belakang dan tidak terdapat tonjolan keras (Fitri dan Roesma, 2012). Ikan yang paling banyak ditemukan di Sungai Lulak adalah ikan kemuring (Puntius lineatus) dengan jumlah 42 dan 21 ikan di sungai gendir.

Spesies (Puntius lineatus) merupakan spesies ikan dari genus puntius. Genus puntius memiliki beberapa spesies yang memiliki karakteristik yang berbeda. Spesies yang ditemukan di sungai lulak dan sungai gendir merupakan spesies yang termasuk ke dalam spesies (Puntius lineatus). Hal ini dikarenakan, berdasarkan hasil yang didapat, ikan ini memiliki ciri utama yaitu pola garis di tubuh sebanyak 5-6 garis (Pulungan, 2009). Ikan dari famili speciecyprinidae yang juga banyak ditemukan di Kedua perairan sungai ini adalah ikan dari spesies (Puntius binotatus) dengan nama lokal yaitu Ikan Tanah. (Puntiu.binotatus) memiliki karakter berupa tubuh yang licin, mempunyai empat sungut, gurat sisi sempurna, jari-jari terakhir sirip dorsal mengeras dan bergerigi, 4 1/2 sisik antara gurat sisi dan awal sirip dorsal, bintik hitam pada bagian depan sirip dorsal dan bagian tengah batang ekor, ikan muda dan dewasa memiliki 2 hingga 4 titik atau lonjong di tengah badan (Kottelat et al., 1993).

\begin{tabular}{|c|c|c|c|c|c|c|c|c|c|}
\hline \multirow[b]{2}{*}{ No } & \multirow[b]{2}{*}{$\begin{array}{l}\text { Nama } \\
\text { Lokal }\end{array}$} & \multirow[b]{2}{*}{ Famili } & \multirow[b]{2}{*}{ Spesies } & \multicolumn{2}{|c|}{ Komposisi Jenis } & \multicolumn{2}{|c|}{ Sungai Lulak } & \multicolumn{2}{|c|}{ Sungai Gendir } \\
\hline & & & & $\begin{array}{l}\text { Sungai } \\
\text { Lulak }\end{array}$ & $\begin{array}{l}\text { Sungai } \\
\text { Gendir }\end{array}$ & $\operatorname{KR}(\%)$ & FI $(\%)$ & $\operatorname{KR}(\%)$ & $\mathrm{FI}(\%)$ \\
\hline 1 & Ikan Betok & Anabantidae & Anabas testudineus & 0 & 1 & 0 & 0 & 1,042 & 33,33 \\
\hline 2 & Ikan Baung & Bagridae & Mystus nemurus & 3 & 13 & 2,439 & 100,00 & 13,542 & 100,00 \\
\hline 3 & Ikan Gabus & Channidae & Channa striata & 1 & 0 & 0,813 & 33,33 & 0 & 0 \\
\hline
\end{tabular}

Tabel 1. Komposisi Jenis Ikan Yang di dapatkan di Sungai Lulak dan Sungai Gendir. 


\begin{tabular}{|c|c|c|c|c|c|c|c|c|c|}
\hline 4 & Ikan & & & & & 34,146 & 100,00 & 21,875 & 100,00 \\
\hline \multirow{3}{*}{5} & Kemuring & Cyprinidae & Puntius lineatus & 42 & 21 & \multirow{3}{*}{13,008} & \multirow{3}{*}{100,00} & \multirow{3}{*}{29,167} & \multirow{3}{*}{100,00} \\
\hline & Ikan & Cynrinidae & Cyclocheilichthys & & & & & & \\
\hline & Keperas & cyprinidae & apogon & 16 & 28 & & & & \\
\hline 6 & Ikan Tanah & Cyprinidae & Puntius binotatus & 26 & 16 & 21,138 & 100,00 & 16,667 & 100,00 \\
\hline 7 & Ikan Kepait & Cyprinidae & Osteochilus spilurus & 6 & 0 & 4,878 & 66,67 & 0 & 0 \\
\hline 8 & $\begin{array}{l}\text { Ikan } \\
\text { Seluang }\end{array}$ & Cyprinidae & $\begin{array}{c}\text { Rasbora } \\
\text { chepholataenia }\end{array}$ & 4 & 1 & 3,252 & 33,33 & 1,042 & 33,33 \\
\hline 9 & $\begin{array}{c}\text { Ikan } \\
\text { Ketiber }\end{array}$ & Nandidae & Nandus nebulosus & 0 & 1 & 0 & 0 & 1,042 & 33,33 \\
\hline 10 & $\begin{array}{c}\text { Ikan } \\
\text { Kelincah }\end{array}$ & Osphronemidae & Belontia haselti & 3 & 3 & 2,439 & 33,33 & 3,125 & 33,33 \\
\hline 11 & Ikan Sepat & Osphronemidae & $\begin{array}{l}\text { Trichogaster } \\
\text { trichopterus }\end{array}$ & 12 & 8 & 9,756 & 66,67 & 8,333 & 66,67 \\
\hline 12 & $\begin{array}{c}\text { Ikan } \\
\text { Tempalak }\end{array}$ & Osphronemidae & Betta anabatoides & 2 & 2 & 1,626 & 33,33 & 2,083 & 33,33 \\
\hline 13 & $\begin{array}{c}\text { Ikan } \\
\text { Kepatung }\end{array}$ & Peristolepididae & Pristolepis grootii & 6 & 2 & 4,878 & 66,67 & 2,083 & 33,33 \\
\hline 14 & Ikan Lelais & Siluridae & Kryptopterus lais & 2 & 0 & 1,626 & 33,33 & 0 & 0 \\
\hline
\end{tabular}

Kelimpahan relatif suatu spesies merupakan nilai persentase banyaknya spesies ikan yang ditemukan disbandingkan dengan keseluruhan total individu semua spesies, sedangkan nilai frekuensi keterdapatan adalah nilai yang menunjukkan luasnya persebaran lokasi jenis ikan yang didapatkan dari perhitungan banyaknya jumlah stasiun dimana ikan ditemukan dibandingkan dengan jumlah total stasiun penelitian. Hasil kelimpahan relatif dan Frekuensi keterdapatan yang di dapat di sungai Lulak yang tertinggi ialah famili dari Cyprinidae yaitu ikan Kemuring (Puntius lineatus) dengan nilai $\mathrm{Kr} 34,146 \%$ dan nilai Fi 100,00\%, sedangkan di Sungai Gendir ialah ikan Keperas (Cyclocheilichthys apogon) dengan nilai Kr 29,167\% dam nilai Fi 100,00\%. Berdasarkan hasil tersebut, Ikan Kemuring di Sungai Lulak merupakan ikan yang paling banyak ditemukan di perairan tersebut dengan persentase sebesar 34,146\% dari total 11 jenis spesies yang ditemukan. Frekuensi keterdapatan ikan Kemuring dan Ikan Keperas menunjukkan bahwa ikan tersebut tersebar merata di ketiga stasiun yang berarti selalu ditemukan ikan dari jenis tersebut pada tiap stasiun penelitian. Apabila dilihat dari pola penyebarannya, Ikan Kemuring (Puntius lineatus) dan Ikan Keperas (Cyclocheilichthys apogon) menyebar secara luas pada musim penghujan dari hulu ke hilir pada semua sungai. Famili Cyprinidae memang telah dikenal sebagai penghuni utama yang paling besar populasinya untuk beberapa sungai (Fithra, 2010).

Untuk nilai Kelimpahan relatif dan Frekuensi keterdapatan terendah di kedua sungai ialah didapatkan hasil di Sungai Lulak Ikan Gabus (Channa striata)

famili dari Channidae dengan nilai $\mathrm{Kr} 0,813 \%$ dan nilai Fi 33,33\%, sedangkan di sungai Gendir Ikan Betok (Anabas testudineus) famili dari Anabantidae, Ikan Ketiber (Nandus nebulosus) famili dari Nandidae dan Ikan Seluang (Rasbora Cepholotaenia) famili dari Cyprinidae dengan nilai $\mathrm{Kr}$ 1,042\% dan nilai Fi 33,33\%. Hal ini menunjukkan bahwa Ikan Gabus hanya ditemukan sebanyak $0,813 \%$ dari total jumlah jenis ikan secara keseluruhan. Nilai frekuensi keterdapatan berupa 0 menunjukkan bahwa tidak ditemukan ikan jenis tersebut pada semua stasiun penelitian. Tinggi nilai frekuensi keterdapatan (100\%) menunjukkan jenis ikan tersebut memiliki luas peneyebaran yang relatif besar di sepanjang Sungai Lulak dan Sungai Gendir, sebaliknya rendah nilai frekuensi keterdapatan (33\%) menunjukkan bahwa jenis ikan tersebut memiliki luas sebaran yang relatif sempit (Setyobudiandi et al.,2009).

Ikan lain yang ditemukan pada perairan Sungai Lulak adalah ikan kelincah (Belontia haselti), Ikan sepat (Trichogaster trichopterus), dan Ikan tempalak (Betta anabatoides) yang merupakan ikan dari famili Osphronemidae, Ikan Kepatung (Pristolepis grootii) dari famili Pristolepididae dan ikan lelais (Kryptopterus lais) dari famili Siluridae. Secara kesuluruhan, struktur komunitas perairan Sungai Lulak dan Sungai Gendir terdapat 8 famili yang ditemukan. Kedua perairan tersebut sama-sama didominasi oleh famili cyprinidae. Perairan sungai lulak terdiri dari 8 famili yaitu Bagridae, Channidae, Cyprinidae, Osphronemidae, Pristolepididae, dan Siluridae, sedangkan perairan sungai gendir terdiri dari Anabantidae, Bagridae, Cyprinidae, Nandidae, Osphronemidae, dan Pristolepididae. Nilai indeks keanekaragaman di Sungai Lulak dan Sungai Gendir tergolong sedang dengan nilai 1,881 - 1,947, dimana nilai indeks keanekaragaman pada Sungai Lulak sebesar 1,947 dan nilai indeks keanekaragaman Sungai Gendir sebesar 1,881. Nilai indeks keseragaman di kedua sungai memiliki nilai yang sama yaitu sebesar 0,784, dimana nilai tersebut tergolong tinggi.

\section{Struktur Komunitas Ikan Sungai Lulak dan Sungai Gendir}

Berdasarkan data penelitian, tidak terdapat perbedaan yang jauh antara struktur komunitas di Sungai Lulak dan Sungai Gendir. Tabel 2. Menyajikan data Indeks dominansi, keanekaragaman dan indeks kesereagaman dalam menganalisis struktur komunitas.

Tabel 2. Struktur Komunitas Ikan Sungai Lulak dan Sungai Gendir

\begin{tabular}{cccc}
\hline $\begin{array}{c}\text { Nama } \\
\text { Sunga } \\
\mathbf{i}\end{array}$ & $\begin{array}{c}\text { Keanekaragama } \\
\mathbf{n}\left(\mathbf{H}^{\prime}\right)\end{array}$ & $\begin{array}{c}\text { Keseragama } \\
\mathbf{n}(\mathbf{E})\end{array}$ & $\begin{array}{c}\text { Dominans } \\
\mathbf{i}(\mathbf{C})\end{array}$ \\
\hline Lulak & 1,948 & 0,784 & 0,195
\end{tabular}


Gendir

1,881

0,784

0,188

Nilai indeks keanekaragaman di Sungai Lulak dan Sungai Gendir tergolong sedang dengan nilai 1,881 - 1,947, dimana nilai indeks keanekaragaman pada Sungai Lulak sebesar 1,947 dan nilai indeks keanekaragaman Sungai Gendir sebesar 1,881. Nilai indeks keseragaman di kedua sungai memiliki nilai yang sama yaitu sebesar 0,784 , dimana nilai tersebut tergolong tinggi

Indeks diversitas atau indeks keanekaragaman ikan merupakan sebuah gambaran tentang kekayaan ikan atau banyak sedikitnya jenis ikan yang ada di kawasan tersebut. Hasil dari nilai keanekaragaman akan tergantung pada variasi banyaknya individu yang ada pada setiap spesies yang dijumpai, sehingga semakin tinggi jumlah spesies dan variasi jumlah individu yang ada tiap spesies maka keanekaragaman yang ada pada ekosistem tersebut akan semakin besar (Sriwidodo, 2013). Struktur komunitas merupakan suatu konsep yang mempelajari susunan atau komposisi spesies dan kelimpahannya dalam suatu komunitas. Secara umum ada tiga pendekatan yang dapat digunakan untuk menggambarkan struktur komunitas yaitu keanekaragaman spesies, keseragaman spesies dan dominansi spesies (Schowalter, 1996). Berdasarkan hasil penelitian, nilai indeks keanekaragaman $\left(\mathrm{H}^{\prime}\right)$ yang ada di dua lokasi penilitian menunjukkan nilai sebesar 1,948 untuk Sungai Lulak dan 1,881 untuk Sungai Gendir. Hal ini menunjukkan bahwa keanekeragaman jenis di ke dua sungai menunjukkan bahwa indeks keanekaragaman berada pada kategori keanekeragaman sedang. Penentuan kategori tersebut berpedoman pada Setyobudiandi et al. (2009) yang mengatakan bahwa nilai indeks keanekargaman dengan nilai $1<\mathrm{H}^{\prime}<3$ masuk ke dalam kategori Keanekaragaman sedang. Indeks keanekaragaman ikan pada kategori sedang menunjukkan bahwa pada keanekeragaman pada sungai Lulak dan Sungai Gendir berkembang dengan baik dan mampu mempertahankan kelestariannya di perairan tersebut serta dapat beradaptasi dengan baik dengan lingkungan di perairan tersebut. Dengan kata lain, kondisi perairan baik di sungai Lukak maupun Sungai Gendir sesuai dengan kebutuhan keberlangsungan hidup ikan misalnya kecepatan arus dan ketersediaan sumber makanan. Hal ini didukung Nurudin (2013) yang mengatakan bahwa kondisi perairan seperti kecepatan arus yang stabil memiliki nilai keanekeragaman sedang atau menengah dengan jumlah variasai jenis individu yang tinggi. Selain itu, aktivitas manusia juga mempengaruhi keankeragaman ikan di suatu perairan.

Nilai indeks keseragaman ikan ialah menunjukan adanya jumlah individu yang terkonsentrasi pada satu atau beberapa jenis. Hal ini dapat diartikan ada beberapa jenis biota yang memiliki jumlah jenis individu relatif banyak. Sementara beberapa jenis lainnya memiliki jumlah individu yang relatif sedikit. Nilai indeks keseragaman yang mendekati 1 menunjukan bahwa jumlah individu disetiap spesies adalah sama atau hampir sama. Dari pengambilan sampel yang didapatkan di Sungai Lulak dan Sungai Gendir ialah bernilai 0,784., hal ini Penentuan kriteria berdasarkan Setyobudiandi et al., 2009 bahwa $0,75<\mathrm{E} \leq 1$ menunjukan Keseragaman tinggi. Hal ini dibuktikan dari jenis ikan kemuring (Puntius lineatus) yang memiliki junlah individu sangat banyak yaitu di Sungai Lulak 42 individu dan di Sungai Gendir yang memiliki jumlah paling banyak yaitu ikan keperas (Cyclocheilichthys apogon) berjumlah 28 individu.

Sementara jenis ikan yang sangat sedikit didapat di Sungai Lulak ikan gabus (Channa striata) hanya 1 individu saja, sedangkan Sungai Gendir yang sangat sedikit di dapat ikan Seluang (Rasbora chepalotenia), ikan Betok (Anabas testudineus), ikan Ketiber (Nandus nebulosus) hanya 1 individu yang didapatkan. Tingginya nilai indeks keseragaman di Sungai Lulak dan Sungai Gendir mengartikan keberadaan setiap jenis ikan di perairan dalam kondisi merata. Sungai Lulak dan Sungai Gendir memiliki nilai yang tinggi namun nilai keanekaragaman sedang, hal ini berarti menunjukan keseimbangan antara jumlah individu dengan jenis yang didapatkan pada saat sampling. Artinya tidak ada jenis tertentu yang memiliki jumlah individu dominan. Keberadaan ikan Gabus (Channa striata) yang sedikit dikarenakan ikan gabus merupakan ikan yang aktif dimalam hari sedangkan pengambilan data dilakukan pada siang hari. Ikan gabus memiliki sifat nokturnal yakni aktif mencari makan pada malam hari (Wahyuni et al. 2017).

\section{Parameter Fisika-Kimia Kualitas Perairan}

Data Kualitas perairan Sungai Lulak dan Sungai Gendir secara lengkap disajikan pada Tabel 3.

Tabel 3. Parameter Kualitas Fisika - Kimia Perairan Sungai Lulak dan Sungai Gendir.

\begin{tabular}{|c|c|c|c|}
\hline No & Parameter & $\begin{array}{l}\text { Sungai } \\
\text { Lulak }\end{array}$ & $\begin{array}{l}\text { Sungai } \\
\text { Gendir }\end{array}$ \\
\hline 1 & Suhu $\left({ }^{\circ} \mathrm{C}\right)$ & 31 & 30 \\
\hline 2 & $\begin{array}{l}\text { Kecepatan Arus } \\
(\mathrm{m} / \mathrm{s})\end{array}$ & 0,113 & 0,109 \\
\hline 3 & $\mathrm{pH}$ & 6 & 5,5 \\
\hline 4 & Kecerahan $(\mathrm{cm})$ & 99,67 & 83,3 \\
\hline 5 & Kedalaman (m) & 2,25 & 1,7 \\
\hline 6 & DO (mg/L) & 4,13 & 4,23 \\
\hline 7 & $\mathrm{NO}_{3}(\mathrm{mg} / \mathrm{L})$ & 0,66 & 0,62 \\
\hline 8 & $\mathrm{PO}_{4}(\mathrm{mg} / \mathrm{L})$ & 0,18 & 0,13 \\
\hline
\end{tabular}

Parameter lingkungan yang di ambil pada penelitian ini terdiri dari parameter fisika (Suhu, Kecepatan Arus, Kecerahan dan kedalaman) sedangkan parameter kimia yang diambil adalah ( $\mathrm{pH}$, Nitrat, Fosfat, DO). Suhu perairan di Sungai Lulak ialah sbesar $31{ }^{\circ} \mathrm{C}$ sedangkan suhu perairan sungai Gendir yang menjadi lokasi penelitian lebih rendah ssatu angka yaitu sebesar $30{ }^{\circ} \mathrm{C}$. Suhu berperan penting dalam kelangsungan hidup ikan di perairan. Ikan dari famili cyprinidae adalah ikan yang mendominasi struktur komunitas di kedua perairan salah satunya adalah ikan dari genus Puntius. Menurut Supanji (2018), menyatakan bahwa ikan tempuring Puntius spp di sungai tua tunu hidup pada suhu $28^{\circ} \mathrm{C}$ $29^{\circ} \mathrm{C}$. Sedangkan menurut Mandelasari et al. (2015) menyatakan bahwa genus Puntius spp ini hidup pada suhu $27^{\circ} \mathrm{C}-30^{\circ} \mathrm{C}$ hal ini menunjukkan bahwa umumnya 
ikan dari genus Puntius spp hidup pada suhu $27^{\circ} \mathrm{C}-31^{\circ} \mathrm{C}$. Hal ini menunjukkan bahwa kondisi suhu pada perairan sungai Lulak dan sungai Gendir merupakan suhu yang cocok sehingga dapat menyokong keberlangsungan hidup ikan dari famili cyprinidae tersebut.

Kondisi perairan sungai sangat erat dengan kecepatan arus pada sungai tersebut. Sungai lulak memiliki kondisi arus dengan kecepatanarus sebesar 0,11 $\mathrm{m} / \mathrm{s}$ sedangkan sungai gendir memiliki kecepatan arus sebesar $0,10 \mathrm{~m} / \mathrm{s}$. Kondisi kecepatan arus dipengaruhi beberapa faktor seperti gesekan dengan daratan, angin disekitar perairan, lokasi sungai dan juga gangguan seperti gulma, sampah atau ganggang yang tumbuh di perairan sungai (Putra, 2016). Kecepatan arus di kedua lokasi masuk kedalam kategori arus berarus lambat. Hal ini sesuai dengan klasifikasi jenis kecepatan arus perairan (Duya, 2008) yang menyatakan bahwa Sungai diklasifikasikan berdasarkan kecepatan arusnya yaitu berarus sangat cepat $(>100 \mathrm{~cm} /$ detik), berarus cepat $(50$ $100 \mathrm{~cm} /$ detik), berarus sedang $(25-50 \mathrm{~cm} /$ detik), berarus lambat (10-25 cm/detik) dan berarus sangat lambat $(<10$ $\mathrm{cm} /$ detik). Genus Puntius spp yang merupakan keluarga Cyprinidae yang hidup didaerah berarus tenang dan hidup didasar lubuk-lubuk pada sungai (Duya, 2008). peraran sunga Lulak memiliki kecerahan yang lebih tinggi dibandingkan kecerahan perairan Sunga Gendir. Nilai kecerahan sunga lulak ialah 99,67 cm sedangkan Sungai Gendir ialah sebesar 83, $7 \mathrm{~cm}$. Nilai kecerahan didapatkan dari nila rata-rata kecerahan tiap stasiun di setiap perairan. Kecerahan dipengaruhi oleh banyak sedikitnya cahaya yang masuk ke dalam perairan. Hal ini sesuai dengan pendapat Saraswati et al. (2017) yang mengatakan bahwa Kecerahan perairan merupakan kemampuan dari cahaya dapat menembus masuk ke dalam perairan.

Kedalaman merupakan salah satu parameter fisika, dimana jika semakin dalam perairan maka intensitas cahaya yang masuk semakin berkurang (Gonawi, 2009). Kedalaman adalah suatu tempat penyebaran atau faktor fisik yang berhubungan dengan banyak air yang masuk kedalam suatu sistem perairan, semakin dalam sungai maka akan semakin banyak jumlah ikan yang menempati perairan tersebut. (Kottelat et al., 1993 dalam Supanji, 2018).

Berdasarkan nilai $\mathrm{pH}$ yang didapatkan pada penelitian di Sungai Lulak bernilai 6, sedangkan di Sungai Gendir bernilai 5,5. Berdasarkan data penelitian yang dilakukan, famili yang mendominasi ialah Cyprinidae karena banyak ditemukan di kedua lokasi yaitu, sungai Lulak dan Sungai Gendir. Ikan-ikan yang mendominasi ialah Ikan Kemuring (Puntius lineatus), Ikan Tanah (Puntius binotatus), Ikan Keperas , (Cyclocheilichthys apogon), Ikan Kepait (Osteochilus spilurus), Ikan Seluang (Rasbora chepholataenia). Kadar nitrat diperaran sungai lulak ialah sebesar $0,66 \mathrm{mg} / \mathrm{L}$ sedanglan pada perairan sungai gendir sebesar 0,62 $\mathrm{mg} / \mathrm{L}$. Menurut Effendi (2003) Kadar nitrat-nitrogen yang lebih dari $0,2 \mathrm{mg} / \mathrm{liter}$ dapat mengakibatkan terjatinya eutrifikasi (pengayaan) perairan, yang selanjutnya menstimulir pertumbuhan alga dan pertumbuhan air secara pesat (blooming). Hal ini dikarenakan Nitrogen merupakan kandungan dari protoplasma dan dibutuhkan fitoplankton untuk mensintesis protein (Putri et al, 2014). Keberadaan (blooming) alga atau pertumbuhan alga dan pertumbuhan air secara pesat dapat menutup permukaan perairan sehingga penetrasi cahaya yang masuk ke perairan menjadi berkurang.

Nilai fosfat yang didapatkan pada sungai Lulak adalah sebesar $0,18 \mathrm{mg} / \mathrm{L}$ sedangkan di perairan sungai Gendir ialah sebesar $0,13 \mathrm{mg} / \mathrm{L}$. Berdasarkan PP NO. 82 Tahun 2001 nilai fosfat lewat batas maksimum yang diperbolehkan yaitu $0,2 \mathrm{mg} / \mathrm{L}$ sehingga dapat dikatakan bahwa kedua perairan berada di bawah nila maksimum sehingga masuk ke dalam kategori tidak tercemar. Berdasarkan penelitian yang dilakukan didapatkan nilai kadar oksigen di Sungai Lulak bernilai 4,13 (mg/l) dan di Sungai Gendir bernilai 4,23 (mg/l). Menurut Effendi (2003) kadar oksigen terlarut pada perairan alami biasanya kurang dari $10 \mathrm{mg} / \mathrm{l}$. secara keseluruhan nilai oksigen terlarut di setiap Perairan Sungai Lulak dan Sungai Gendir masih dapat mendukung pertumbuhan ikan.

\section{KESIMPULAN DAN SARAN}

\section{Kesimpulan}

1. Terdapat total 14 jenis ikan yang ditemukan dikedua sungai yang terdiri dari 8 famili (Cyprinidae, Channidae, Siluridae, Bagridae, Peristolepididae, Osphronemidae, Anabantidae dan Nandidae) Terdapat 12 jenis ikan di Sungai Lulak dan 11 jenis ikan di Sungai Gendir.

2. Struktur Komunitas ikan di Sungai Lulak dan Sungai Gendir terdiri dari Indeks keanekaragaman ikan $\left(\mathrm{H}^{\prime}\right)$ sebesar 1,948 untuk sungai Lulak dan 1,881 Sungai Gendir dengan kategori keanekaragaman sedang, Nilai Keseragaman (E) Sungai Lulak dan Sungai Gendir adalah sama yaitu 0,784, serta Dominansi (C) sebesar 0,195 untuk Sungai Lulak dan 0,188 untuk Sungai Gendir.

3. Kedua sungai memiliki kualitas perairan yang berbeda namun masih berada pada ambang batas kualitas perairan yang baik untuk kehidupan ikanikan air tawar yang ditemukan pada kedua sungai ( Sungai Lulak dan Sungai Gendir).

\section{Saran}

Saran dalam penelitian ini perlu di lakukan penelitian lanjutan secara berkala pada peraian Sungai Lulak dan Sungai Gendir agar bertujuan untuk mengetahui perubahan yang terjadi terhadap kondisi keanekaragaman serta kelimpahan ikan yang terdapat di Sungai Lulak dan Sungai Gendir. Serta penelitian lanjutan pada musim panas berlangsung di Sungai Lulak dan Sungai Gendir

\section{UCAPAN TERIMA KASIH}

Penulis mengucapkan terimakasih kepada Universitas Bangka Belitung dan Program Studi Manajemen Sumberdaya Perairan yang telah menyediakan fasilitas penelitian seperti laboratorium sehingga penelitian dapat terlaksana. Selain itu, penulis juga mengucapkan terimakasih kepada teman-teman 
yang sudah membantu dalam penelitian baik dalam bentuk sumbangan pikiran maupun dan tenaga hingga penelitian ini terlaksana.

\section{DAFTAR PUSTAKA}

Duya, N. 2008. Ichtiofauna perairan di Sungai Musi Kejalo Curup Bengkulu. GRADIEN: Ilmiah MIPA. 4(2).394-396.

Effendi, H. 2003. Telaah Kualitas Air Bagi Pengelolaan Sumberdaya dan Lingkungan Perairan. Kanisus. Yogyakarta: p180.

Fachrul MF. 2006. Metode Sampling Bioekologi. PT Bumi Aksara. Jakarta: p30.

Fitri, D. K., \& Roesma, D. I. 2012. Analisis Morfologi Ikan Puntius binotatus Valenciennes 1842 (Pisces: Cyprinidae) dari beberapa Lokasi di Sumatera Barat. Biologi UNAND, 1(2).

Gonawi G R . 2009. Habitat Struktur Komunitas Nekton di Sungai Cihideung-Bogor Jawa Barat [Skripsi]. Program Studi Manajemen Sumberdaya Perairan, Institut Pertanian Bogor. Bogor.

Hargarave C, 2009. Effects of fish spesies richness and assemblage composition on stream ecosystem function. Ecol freshw fish. 18(1):24-32.

Kottelat M, AJ Whitten, SN Kartikasari \& S Wirjoatmodjo. 1993. Freshwater Fishes of Western Indonesia and Sulawesi- Ikan Air Tawar Indonesia Bagian Barat dan Sulawes. Periplus Editions LTD. Hongkong. P78.

Mandelasari, G. D., Efawani, E., \& Efizon, D. 2015. Inventarization and Identification of Fish in the Parit Belanda River Rumbai Pesisir District Pekanbaru, Riau. [Disertasi]. Program Studi Manajemen Sumberdaya Perairan. Universitas Riau. Riau.

Muchlisin, Z.A., dan M.N. Siti-Azizah. 2009. Diversity and distribution of freshwater fishes in Aceh waters, northern Sumatera, Indonesia. International Journal of Zoological Research. 7 (5): 62-79.

Peraturan Pemerintah Republik Indonesia Nomor 82 Tahun 2001 Tentang Pengelolaan Kualitas Airdan Pengendalian Pencemaran. Jakarta. Kementrian Lingkungan Hidup.
Pulungan, C. P. 2009. Fauna ikan dari Sungai Tenayan, anak sungai Siak, dan rawa di sekitarnya, Riau. Berkala Perikanan Terubuk, 37(2).

Putra, I. S. 2016. Studi Pengukuran Kecepatan Aliran pada Sungai Pasang Surut. INFO-TEKNIK, 16(1), 33-46.

Putri, F. D., Widyastuti, E., \& Christiani, C. 2014. Hubungan Perbandingan Total Nitrogen dan Total Fosfor dengan Kelimpahan Chrysophyta di Perairan Waduk Panglima Besar Soedirman, Banjarnegara. Scripta Biologica, 1(1), 92-97.

Saraswati, N. L. G. R. A., Rustam, A., Salim, H. L., Heriati, A., \& Mustikasari, E. 2017. Kajian Kualitas Air Untuk Wisata Bahari Di Pesisir Kecamatan Moyo Hilir Dan Kecamatan Lape, Kabupaten Sumbawa. Segara, 13(1).

Schowalter. 1996. Insect Ecology: An Ecosytem Approach Academic Press. San Diego.

Setyobudiandi I, Sulistino, Ferdinan Y, Kusuma C, Hariadi S, Damar A, Sembiring A dan Bahtiar. 2009. Sampling dan Analisis Data Perikanan dan Kelautan Terapan Metode Pengambilan Contoh di Wilayah Pesisir dan Laut. Fakultas Perikanan dan Ilmu Kelautan IPB.

Sriwidodo, D. W. E., Budiharjo, A., \& Sugiyarto, S. 2013. Keanekaragaman jenis ikan di kawasan inlet dan outlet Waduk Gajah Mungkur Wonogiri. Bioteknologi Biotechnological Studies, 10(2), 43-50.

Supanji R. 2018. Struktur Komunitas Ikan Air Tawar Yang Terdapat Di Sungai Lubuk Bakong Tua Tunu Pangkalpinang.[Skripsi]. Program Studi Manajemen Sumberdaya Perairan.Universitas Bangka Belitung. Bangka Belitung.

Wahyuni, S., Windarti, W., \& Putra, R. M. 2017. Comparative Study On Histological Structure Of Gill And Kidney Of Snakehead Fish (Channa Striata, BLOCH 1793) From The Kulim And Sibam Rivers, [Disertasi]. Program Studi Manajemen Sumberdaya Perairan. Universitas Riau. Riau. 